\title{
FOXG1 Gene
}

National Cancer Institute

\section{Source}

National Cancer Institute. FOXG1 Gene. NCI Thesaurus. Code C18413.

This gene is involved in transcriptional repression and may play a role in the development of the brain and telencephalon. 